Original Research Paper

\title{
Diseminasi Informasi Mengenai Tumbuhan Liar Pekarangan yang Berkhasiat Obat sebagai Alternatif Pemeliharaan Kesehatan pada Masa Krisis Ekonomi di Desa Jeringo, Kabupaten Lombok Barat
}

\author{
Baiq Farista ${ }^{1}$, Arben Virgota ${ }^{1}$, Hilman Ayadi ${ }^{1}$, Dining Candri ${ }^{2}$ \\ ${ }^{I}$ Program Studi Ilmu Lingkungan, Fakultas MIPA, Universitas Mataram, Lombok, Indonesia; \\ ${ }^{2}$ Program Studi Biologi, Fakultas MIPA, UNiversitas Mataram
}

https://doi.org/10.29303/jpmpi.v3i2.653

Sitasi: Farista, B., Virgota, A., Ayadi, H., \& Candri, D. (2021). Diseminasi Informasi Mengenai Tumbuhan Liar Pekarangan yang Berkhasiat Obat sebagai Alternatif Pemeliharaan Kesehatan pada Masa Krisis Ekonomi di Desa Jeringo, Kabupaten Lombok Barat. Jurnal Pengabdian Magister Pendidikan IPA, 4(1)

\section{Article history}

Received: 05 Januari 2021

Revised: 19 Februari 2020

Accepted: 05 Maret 2021

*Corresponding Author: Baiq Farista, Program Studi Ilmu Lingkungan, Fakultas MIPA, Universitas Mataram, Lombok, Indonesia;

Email:

\begin{abstract}
In the last few years, the use of medicines made from natural ingredients has returned to people's consumption today because of the assumption that natural ingredients are safer and more economical than chemical drugs. The assumption that natural medicine is safer than chemical drugs. Medicinal plants are types of plants in which certain parts of the roots, stems, bark, leaves or excretions are believed to relieve or reduce pain. Several types of wild medicinal plants found in Jeringo Village are meniran (Phyllanthus urinaria), cat whiskers (Orthosiphon aristatus), bebele / gotu kola (Centella Asiatica), shy daughter (Mimosa pudica) and horse whip (Stachytarpheta jamaicensis). The purpose of this activity is to introduce several types of wild plants that have medicinal properties that grow in the yard, along with how to maintain and process them. It is hoped that from this activity the people of Jeringo will have knowledge and be able to carry out treatment independently by utilizing wild plants as one of the cheap and safe alternative treatments.
\end{abstract}

Keywords: Disseminasi information; Medicinal plants; Jeringo Village.

\section{Pendahuluan}

Desa Jeringo merupakan salah satu desa di Kabupaten Lombok Barat yang cukup subur. Berbagai jenis tumbuhan baik yang sengaja ditanam oleh masyarakat maupun yang tumbuh liar dapat ditemukan di sekitar perumahan penduduk. Banyak dari ragam tumbuhan tersebut yang dimanfaatkan oleh masyarakat untuk memenuhi kebutuhan pangan sehari-hari, namun banyak juga yang manfaatnya belum dikenali oleh masyarakat Desa Jeringo. Di lain pihak, berbagai referensi telah menyebutkan beragam tumbuhan liar yang ada di sekitar pekarangan permukiman penduduk memiliki khasiat sebagai obat. Tumbuhan berkhasiat obat adalah jenis tumbuhan yang pada bagian-bagian tertentu baik akar, batang, kulit, daun maupun hasil ekskresinya dipercaya dapat menyembuhkan atau mengurangi rasa sakit (Noorhidayah \& Sidiyasa, 2006).

Tumbuhan obat memiliki beberapa kelebihan dibanding obat modern. Efek samping dari pengobatan herbal sangat kecil (Winarto, 2007b). Berdasarkan hasil pengujian toksisitas akut LD50, diketahui bahwa tumbuhan obat tidak toksik, tetapi karena perbedaan respon individual terjadi alergi meskipun masih pada kisaran dosis yang aman. Kelebihan lainnya dari tumbuhan obat adalah harga yang relatif murah. Bisa menjadi sangat murah bila ditanam sendiri di halaman rumah. Selain itu, teknik pengolahan yang sederhana, sehingga sangat mudah untuk diolah sendiri. Selanjutnya, penggunaan tumbuhan obat ini relatif aman, tidak memerlukan pengawasan yang 
ketat sehingga pengobatannya bisa dilakukan sendiri tanpa bantuan tenaga medis.

Dalam kondisi sosial ekonomi masyarakat Desa Jeringo yang belum pulih sebagai dampak dari bencana gempa lombok 2018, kebutuhan untuk hidup sehat tetap dituntut, sementara harga obat-obatan kimia dirasa sangat mahal maka pengenalan berbagai jenis tumbuhan sebagai obatobatan menjadi sangat penting. Oleh sebab itu maka dirasa penting untuk melakukan diseminasi informasi mengenai tumbuhan liar pekarangan yang berkhasiat obat sebagai alternatif pemeliharaan kesehatan masyarakat Desa Jeringo, Kabupaten Lombok Barat. Diharapkan dari kegiatan pengabdian ini masyarakat memiliki pengetahuan dan mampu melakukan pengobatan secara mandiri dengan memanfaatkan tumbuhan liar sebagai salah satu alternatif pengobatan yang murah dan aman.

\section{Metode}

Kegiatan Diseminasi tumbuhan liar pekarangan yang berkhasiat obat dilaksanakan pada bulan Februari 2020 di Desa Jeringo, Kabupaten Lombok Barat. Metode yang digunakan dalam kegiatan ini adalah: Ceramah, diskusi dan pelatihan, praktek pemeliharaan tumbuhan liar dengan teknik vertikal garden (vega) dan juga praktek pengolahan tumbuhan liar sebagai obat. Ceramah dan diskusi dilaksanakan untuk mensosialisasikan beberapa jenis tumbuhan liar yang banyak dijumpai di sekitar pekarangan, yang berkhasiat sebagai obat. Penyampaian materi sosialisasi dilakukan secara langsung pada masyarakat oleh narasumber yang kompeten di bidangnya sesuai kebutuhan. Praktek pemeliharaan tumbuhan liar dengan teknik vega dilakukan secara langsung. Rak vega dibuat secara mandiri oleh masyarakat menggunakan bahan alam yang tersedia di sekitar. Pada beberapa area di Desa Jeringo ditumbuhi oleh bambu yang sangat subur. Masyarakat memanfaatkan bambu yang ada untuk membuat rak vega. Praktek pengolahan bahan obat yang berasal dari tumbuhan liar dilakukan dengan cara demonstrasi agar masyarakat paham dan mengerti teknik pengolahan yang tepat.

Adapun tahapan kegiatan pengabdian pada masyarakat ini adalah sebagai berikut:

1. Sosialisasi dan koordinasi dengan semua pihak terkait, kegiatan ini bertujuan untuk mengkomunikasikan rencana kegiatan serta legalisasi kegiatan.

2. Mengumpulkan beberapa jenis tumbuhan liar yang berkhasiat obat dari sekitar pekarangan penduduk. Adapun jenis tumbuhan liar yang dikumpulkan meliputi meniran (Phyllanthus urinaria), kumis kucing (Orthosiphon aristatus), bebele/pegagan (Centella Asiatica), putri malu (Mimosa pudica) dan pecut kuda (Stachytarpheta jamaicensis).

3. Pemberian materi sosialisasi dengan menggunakan metode ceramah dan menggunakan media slide power point yang berisi penjelasan mengenai tumbuhan liar di sekitar permukiman yang berkhasiat sebagai obat. Diperkenalkan 6 jenis tumbuhan liar yang sudah mengalami uji klinik dan dipublikasikan secara ilmiah pada jurnal, terdiri dari khasiatnya secara ilmiah, penanaman dan pemeliharaan, serta materi pengolahannya secara sederhana. Materi mengenai cara pengolahan tumbuhan obat ini juga disampaikan dengan menggunakan leaflet/brosur.

4. Mengedukasi masyarakat untuk melindungi dan menanam tumbuhan yang berkhasiat obat di halaman rumahnya dengan menggunakan teknik vega.

5. Diskusi dan tanya jawab.

\section{Hasil dan Pembahasan}

Tumbuhan liar merupakan tumbuhan yang dalam pertumbuhan maupun perkembangannya tanpa adanya ikut campur tangan manusia, sehingga pertumbuhan maupun perkembangannya sepenuhnya tergantung keadaan alam. Tumbuhan liar yang ada di pekarangan rumah seringkali diabaikan dan dianggap sebagai tumbuhan pengganggu.

Kebanyakan masyarakat Desa Jeringo, Kabupaten Lombok Barat juga belum mengenal potensi jenis-jenis tumbuhan liar yang tumbuh di pekarangan. Beberapa penelitian telah menggali informasi mengenai pemanfaatan tumbuhan liar ini, salah satnya adalah sebagai tumbuhan obat. Kegiatan diseminasi informasi mengenai tumbuhan liar pekarangan yang berkhasiat obat ini bertujuan untuk memperkenalkan beberapa jenis tumbuhan liar yang tumbuh di pekarangan yang berkhasiat 
sebagai obat, berikut cara pemeliharaan dan pengolahannya.

Kegiatan pengabdian ini diawali dengan memperkenalkan beberapa jenis tumbuhan liar yang ditemukan di sekitar pekarangan yang memiliki khasiat sebagai obat. Tumbuhan liar merupakan tumbuhan yang dalam pertumbuhan maupun perkembangannya tanpa adanya ikut campur tangan manusia, sehingga pertumbuhan maupun perkembangannya sepenuhnya tergantung keadaan alam. Kebanyakan masyarakat hanya mengenal tumbuhan liar sebagai tumbuhan pengganggu yang memiliki penampakan yang tidak indah, sehingga seringkali tumbuhan liar ini diabaikan bahkan dimusnahkan dari pekarangan. Berikut ini ini adalah beberapa jenis tumbuhan liar yang dikumpulkan dari pekarangan penduduk:
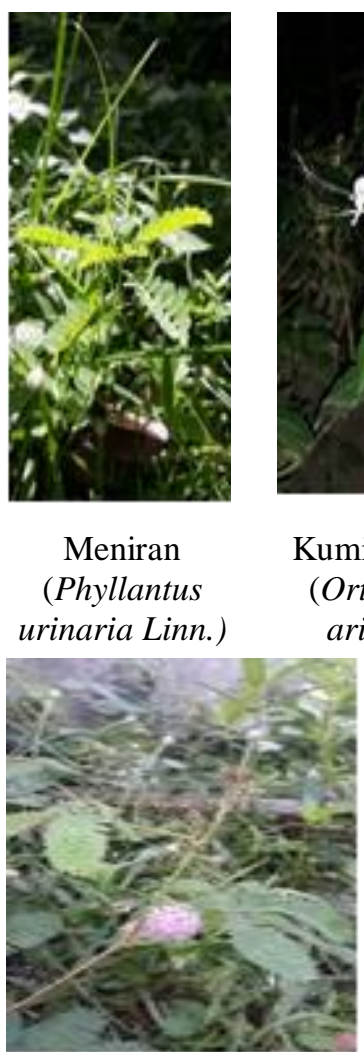

Putri Malu

(Mimosa pudica)
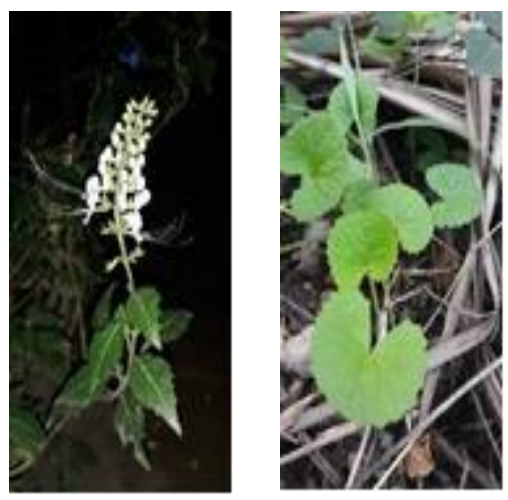

Kumis Kucing (Orthosipon aristatus)
Pegagan

(Centella asiatica)

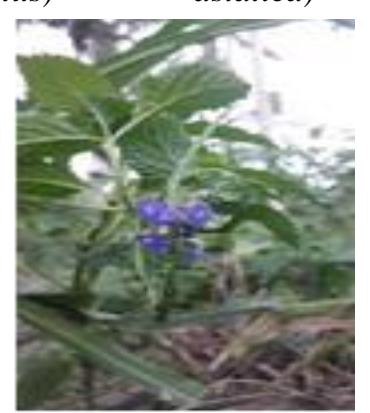

Pecut Kuda

(Stachytarpheta jamaicensis)
Bagian dari tumbuh tumbuhan yang dijadikan obat adalah akar, batang, daun, buah, biji, bunga, kulit, dan paling sering dijadikan obat adalah daun, akar terkadang digunakan dalam pembuatan obat herbal dan obat tradisional. Adapun teknik pengolahan bagian tumbuhan tersebut untuk obat yang diminum adalah dengan merebus ataupun ditumbuk dan diperas airnya. Sedangkan untuk obat pemakaian luar biasanya dengan dihaluskan dan kemudian ditempelkan pada bagian yang sakit (Dalimartha, 2006).
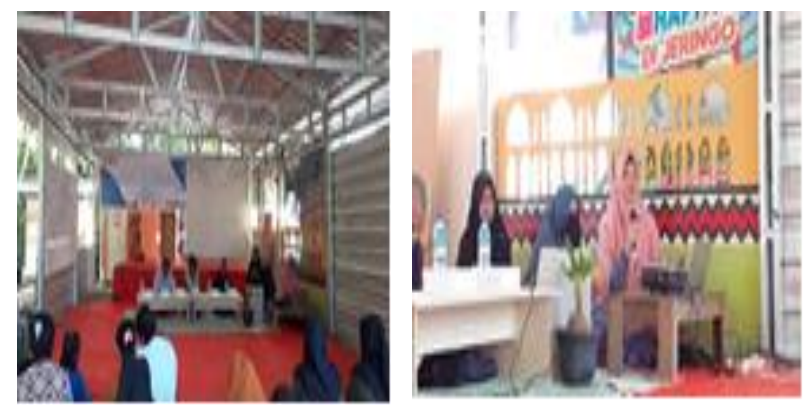

Gambar 2. Kegiatan Diseminasi Informasi mengenai Tumbuhan Liar Pekarangan Berkhasiat Obat

Kegiatan pengabdian ini dilanjutkan dengan memperkenalkan teknik pemeliharaan tumbuhan liar di lahan pekarangan dengan metode kebun bertingkat atau vertical garden (vega). Metode ini dipilih untuk diperkenalkan karena area permukiman di Desa Jeringo terbilang padat. Hal ini disebabkan karena sebaran rumah penduduk terkonsentrasi hanya pada beberapa titik saja. Peserta sangat tertarik untuk menerapkan metode kebun bertingkat ini. Selain mendapatkan manfaat dari hasil kebun, kebun ini juga dapat menambah nilai keindahan desa. Sejak taun 2019, Kepala Desa Jeringo telah merintis pengembangan Desa Jeringo sebagai desa wisata yang mandiri. Peserta berharap kebun bertingkat ini dapat menambah daya tarik Desa Jeringo sebagai destinasi wisata.

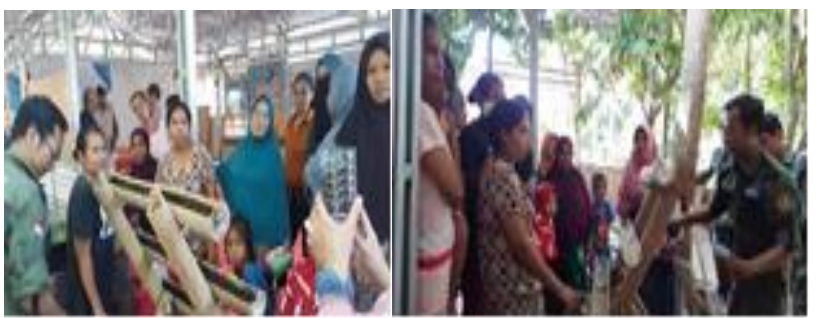

Gambar 3. Praktek pemeliharaan tumbuhan liar berkhasiat obat menggunakan teknik Vega

Umumnya peserta sangat senang mengikuti kegiatan ini, mereka mendapat perspektif baru mengenai ragam jenis tumbuhan yang tumbuh liar di sekitar pekarangan namun memiliki khasiat sebagai obat. Berdasarkan hasil diskusi, diketahui 
bahwa tidak banyak dari anggota masyarakat Desa Jeringo yang telah memanfaatkan jenis jenis tumbuhan yang diperkenalkan sebagai obat. Salah satu jenis tumbuhan liar yang pernah dimanfaatkan oleh masyarakat adalah pegagan yang dalam bahasa lokal disebut Bebele. Beberapa orang anggota masyarakat telah menggunakan Bebele sebagai obat yang bisa menghancurkan batu ginjal. Informasi mengenai Bebele sebagai obat kencing batu diperoleh dari pengalaman teman dan kerabat yang telah terlebih dahulu memanfaatkannya. Di akhir acara masyarakat mempunyai komitmen untuk melindungi tumbuhan liar yang berkhasiat sebagai obat, dan juga akan terus mencari informasi mengenai jenis-jenis tumbuhan liar lainnya yang memiliki khasiat sebagai obat.

Teknik vega juga sangat menarik perhatian peserta. Menurut peserta, teknik vega yang ditata dengan rapi dapat menambah keindahan tampilan pekarangan mereka. Rata-rata peserta memiliki keinginan untuk mencoba semua yang telah dipraktekkan. Masyarakat tertarik memanfaatkan lahan pekarangan mereka untuk memelihara tumbuhan obat dan juga sayur-sayuran dengan teknik vega.

Secara umum, kegiatan pengabdian ini berhasil mencapai target sasaran dengan baik. Dilihat dari segi jumlah peserta dan keterlibatannya secara langsung selama proses diseminasi. Keragaman usia dan latar belakang peserta mulai dari pemuda karang taruna, remaja mesjid dan ibu rumah tangga, yang ingin memanfaatkan tumbuhan liar berkhasiat obat ini sebagai alternatif pemeliharaan kesehatan di Desa Jeringo.

\section{Kesimpulan}

Simpulan dari program pengabdian ini adalah masyarakat Desa Jeringo menyadari bahwa ada banyak jenis tumbuhan liar yang memiliki nilai manfaat yang dapat dirasakan langsung, salah satunya adalah sebagai obat. Teknik pemeliaraan tumbuhan liar dengan metode vega dapat diterapkan dengan mudah, tidak membutuhkan biaya yang besar, namun sangat mendukung upaya menjaga kesehatan masyarakat dan juga keindahan lingkungan desa.

\section{Daftar Pustaka}

Dalimartha, S. (2006). Atlas Tumbuhan Obat Indonesia (Jilid 4).

Wijayakusuma, H. (1992). Tanaman Berkasiat Obat di Indonesia (Jilid I).

Wijayakusuma, H. (1993). Tanaman Berkhasiat Obat di Indonesia (Jilid ke-2).

Winarto, W. . (2007a). Tanaman Obat Indonesia. Untuk Pengobat Herbal (Jilid 2).

Winarto, W. . (2007b). Tanaman Obat Indonesia. Untuk Pengobat Herbal (Jilid 3). Jakarta.: Karyasari Herba Media.

Zuhud, E. A. ., Riswan, S., \& Ekarelawan. (1994). Pelestarian Pemanfaatan Keanekaragaman Tumbuhan Obat Hutan Tropika Indonesia. Bogor, Indonesia: Departemen Konservasi Sumberdaya Hutan Fakultas Kehutanan IPB Dan Lembaga Alam Tropika Indonesia. 